\title{
An Insulin-induced DNA-binding Protein for the Human Growth Hormone Gene
}

\author{
Diane Prager, Saba Gebremedhin, and Shlomo Melmed \\ Division of Endocrinology \& Metabolism, Cedars-Sinai Medical Center-UCLA School of Medicine, Los Angeles, California 90048
}

\begin{abstract}
The control of gene transcription is usually mediated by transacting transcriptional factors that bind to upstream regulatory elements. As insulin regulates transcription of the growth hormone (GH) gene, we tested nuclear extracts from unstimulated and insulin-stimulated Chinese hamster ovarian (CHO) cells for binding to four human GH (hGH) gene promoter oligonucleotide fragments identified as target-binding sequences by DNAse I footprinting. Using a mobility shift assay, an insulininduced DNA-binding protein was identified. This protein binds to two upstream overlapping oligonucleotide sequences. Binding activity is present at low levels in unstimulated CHO cells and is stimulated by insulin treatment with a time course suggesting that protein synthesis is required. Incubation of the cells with cycloheximide and puromycin confirmed that de novo protein synthesis is necessary for the increased binding activity. Competition with excess unlabeled specific competitor oligonucleotides prevented binding, while unrelated similarsized oligonucleotides failed to compete for binding, indicating that the observed DNA-protein complex formation is specific. A protein of $\sim 70-80 \mathrm{kD}$ was detected by gradient gel electrophoresis. In conclusion, insulin-mediated DNA-protein binding has been identified on the upstream hGH promoter, suggesting a trans-active role for insulin in mediating polypeptide hormone gene expression. (J. Clin. Invest. 1990. 85:1680-1685.) transcription factor $\bullet$ mobility shift assay $\bullet$ polypeptide gene
\end{abstract}

\section{Introduction}

Multiple, sequence-specific DNA-protein interactions occur in distinct regulatory regions of genes, the results of which determine the degree of transcriptional activation (1). Purification of these trans-acting factors has allowed biochemical characterization as well as promoter-selective transcription (2-4). Insulin influences the transcriptional rate of several cellular genes (5-10). Although insulin-responsive, consensus DNA sequence(s) have not yet been identified, a nuclear protein that binds to the insulin-stimulated c-fos gene has been described (11). Deletional analysis has been used to localize minimal

Address correspondence to Dr. Shlomo Melmed, Division of Endocrinology \& Metabolism, Room B131, Becker Building, Cedars-Sinai Medical Center, 8700 Beverly Blvd., Los Angeles, CA 90048.

Received for publication 20 April 1989 and in revised form 30 January 1990.

J. Clin. Invest.

(c) The American Society for Clinical Investigation, Inc.

0021-9738/90/05/1680/06 \$2.00

Volume 85, May 1990, 1680-1685 sequences required for inducible regulation. Insulin-responsive elements have been described for the rat phosphoenolpyruvate carboxykinase gene (PEPCK) ${ }^{1}$ (12), human glyceraldehyde-3-phosphate dehydrogenase gene (13), and mouse amylase genes (6). We recently reported that the $5^{\prime}$ flanking region of the human growth hormone (hGH) gene contains an insulin-responsive element (14), in addition to previously documented tissue-specific sequences (15). We postulated that an IRE would interact with ubiquitous trans-active nuclear proteins. The hGH gene therefore serves as a useful model to analyze insulin-mediated transcriptional control mechanisms. The ovary contains abundant insulin receptors (16), and insulin has been shown to regulate the expression of several genes in both normal ovarian tissue (17) and in Chinese hamster ovary (CHO) cell lines (18). As CHO cells are a homogenous cell line containing large numbers of insulin receptors (19), they were used as a relatively abundant source of nuclear protein for these experiments. These $\mathrm{CHO}$ nuclear extracts were tested for insulin-responsive proteins binding to the hGH gene 5 flanking region. The results show that this cell type contains nuclear binding activity detectable by mobility shift assay that binds in a sequence-specific manner to the hGH promoter. This trans-acting protein is responsive to insulin treatment.

\section{Methods}

Protein extracts. CHO cells were grown to confluence on $225-\mathrm{cm}^{2}$ plates in Ham's F12 medium in the presence of $10 \%$ (vol/vol) fetal calf serum (Gibco Laboratories, Grand Island, NY), penicillin $(100 \mathrm{U} / \mathrm{ml})$, and streptomycin $(100 \mu \mathrm{g} / \mathrm{ml})$. For insulin treatment, the medium was replaced with Ham's F12 containing 1\% BSA. Insulin (Humulin R) was obtained from Eli Lily and Co. (Indianapolis, IN). $14 \mathrm{nM}$ insulin was added to the incubations for 2-16 h. Nuclear extracts were prepared by a modification of the method of Dignam et al. (20). Briefly, cells were washed with cold PBS and scraped into $5 \mathrm{ml}$ PBS. After centrifugation $(500 \mathrm{~g}$ for $5 \mathrm{~min}$ ) cells were resuspended in hypotonic buffer $(10 \mathrm{mM}$ Tris [pH 7.9], $1.5 \mathrm{mM} \mathrm{MgCl}, 10 \mathrm{mM} \mathrm{KCl}, 0.5 \mathrm{mM}$ DTT) and kept on ice for $10 \mathrm{~min}$. Cells were then homogenized with a glass douncer (type B) and the nuclei sedimented by centrifugation $(1,000 \mathrm{~g}$ for $5 \mathrm{~min}$ ). Nuclei were resuspended in $20 \mathrm{mM}$ Tris (pH 7.9), $20 \%$ glycerol, $1.5 \mathrm{mM} \mathrm{MgCl}_{2}, 0.5 \mathrm{mM} \mathrm{DTT}$, and $4 \mathrm{M} \mathrm{KCl}$ to a final concentration of $0.3 \mathrm{M} \mathrm{KCl}$. After mixing for $30 \mathrm{~min}$ at $4^{\circ} \mathrm{C}$ the suspension was centrifuged $(13,000 \mathrm{~g}$ for $15 \mathrm{~min})$ and dialyzed against $20 \mathrm{mM}$ Tris (pH 7.9), $20 \%$ glycerol, $0.1 \mathrm{M} \mathrm{KCl}, 0.2 \mathrm{mM}$ EDTA, and $0.5 \mathrm{mM}$ DTT. The dialysate was then centrifuged $(13,000 \mathrm{~g}$ for 15 min), aliquotted, and stored at $-70^{\circ} \mathrm{C}$. Effective cell lysis was confirmed by microscopy. All extracts were prepared in the presence of 10 $\mathrm{mM}$ sodium molybdate. Cycloheximide and puromycin were pur-

1. Abbreviations used in this paper: $\mathrm{CHO}$, Chinese hamster ovary; hGH, human growth hormone; PEPCK, phosphoenolpyruvate carboxykinase. 
chased from Sigma Chemical Co. (St. Louis, MO). Protein concentration was determined by the method of Bradford (21).

DNA fragments and oligonucleotides. The sequences used in the binding assays are depicted in Fig. 1. Complementary oligonucleotide sequences synthesized at the UCLA Molecular Biology Institute (core facility) were annealed. The sequences contained 5 ' protruding ends to facilitate labeling with klenow polymerase and deoxyribonucleoside triphosphates. Labeled double-stranded oligonucleotides were purified by polyacrylamide gel electrophoresis and elution of DNA fragments, followed by ethanol precipitation.

Gel shift assays. Binding reactions were performed with 3-5 ng DNA, 1-4 $\mu \mathrm{g}$ poly (dI-dC), and the indicated amounts of protein extract in a buffer containing $10 \mathrm{mM}$ Tris- $\mathrm{HCl}(\mathrm{pH} 7.5), 50 \mathrm{mM} \mathrm{NaCl}$, $5 \mathrm{mM} \mathrm{MgCl}_{2}, 1 \mathrm{mM}$ EDTA, $50 \mathrm{mM} \mathrm{KCl}, 1 \mathrm{mM} \mathrm{DTT}$, and $5 \%$ glycerol (22). Reaction mix was incubated at room temperature for $15 \mathrm{~min}$ then loaded onto 4-6\% polyacrylamide gels and electrophoresed at $10 \mathrm{~V} / \mathrm{cm}$ for $90 \mathrm{~min}$ in $0.5 \times \mathrm{TBE}(1 \times \mathrm{TBE}=50 \mathrm{mM}$ Tris, $50 \mathrm{mM}$ boric acid, and $1 \mathrm{mM}$ EDTA) at $4^{\circ} \mathrm{C}$. The gels were dried and autoradiographed. Competitor DNA (100-fold molar excess) was added $10 \mathrm{~min}$ before labeled DNA and the incubation continued for a further $15 \mathrm{~min}$ before gel loading. For some experiments $3-25 \%$ polyacrylamide gradient gels were prepared (23). Samples from a typical binding reaction were then electrophoresed at $10 \mathrm{~V} / \mathrm{cm}$ at $4^{\circ} \mathrm{C}$ together with prestained high molecular weight markers (Bethesda Research Laboratories, Gaithersburg, MD) until no further migration was observed. $1 \times$ TBE buffer was used. Gels were then processed as described.

\section{Results}

An insulin-inducible DNA-binding protein binds to an upstream sequence. The mechanism of insulin effects on the hGH promoter was examined using the synthesized oligonucleotide fragments depicted in Fig. 1. Footprinting experiments on the $5^{\prime}$ hGH have indicated that sequences $-290 /-264,-273 /-252,-140 /-100$, and $-93 /-66$ are protected (15) and correspond to oligonucleotides A, B, and D depicted in Fig. 1. Nuclear extracts from unstimulated and insulin-stimulated $\mathrm{CHO}$ cells were assayed for binding to the four oligonucleotide fragments. Equal amounts of both unstimulated and stimulated extracts were incubated with each radiolabeled oligonucleotide probe and tested for binding activity in mobility shift assays. Specific binding was only demonstrated using two of the oligonucleotide fragments, A and B (Fig. 2). Binding activity of nuclear extracts derived from control $\mathrm{CHO}$ cells was barely detectable. In contrast, $\mathrm{CHO}$ nuclear extracts derived from cells treated with $14 \mathrm{nM}$ insulin demonstrated an enhanced DNA-binding activity as evidenced by a retarded DNA-protein complex, B3, depicted in Fig. 2. The larger complexes were not appreciably altered by insulin treat- ment. Boiling the extracts before their inclusion in the assay abolished DNA-protein complex formation. The results indicate the presence of an insulin-inducible DNA-binding protein that binds to two upstream overlapping oligonucleotide sequences, $-290 /-264$ and $-273 /-252$. Incubation of $\mathrm{CHO}$ nuclear extract with oligonucleotides $\mathrm{C}$ and $\mathrm{D}$ failed to show specific DNA-protein binding (data not shown).

To demonstrate the specificity of the observed nuclear protein binding to these DNA regions, competition reactions were performed after a 10 -min preincubation with excess unlabeled competitor oligonucleotide fragments (Fig. 2, $-290 / 264+A, B$ and $-273 / 252+A, B)$. Both unlabeled oligonucleotides $A$ and $B$ prevented the formation of the indicated retarded complex when incubated with nuclear extract and radiolabeled oligonucleotide fragments $\mathrm{A}$ and $\mathrm{B}$. This respective cross-competition of unlabeled oligonucleotide $A$ for binding to oligonucleotide $B$ and vice versa implies that the protein recognizes the same sequence. Unlabeled, unrelated oligonucleotides did not prevent binding (data not shown), indicating that the binding is specific for oligonucleotides $\mathrm{A}$ and $\mathrm{B}$.

Kinetics of insulin-induced protein binding in CHO extract. $\mathrm{CHO}$ cells were incubated in serum-free medium with or without insulin (14 $\mathrm{nM}$ ) for the indicated time periods (Fig. 3). The arrow indicates the enhanced binding of the insulin-induced protein to the $-290 /-264$ oligonucleotide after $8 \mathrm{~h}$ treatment, with no further increase after $16 \mathrm{~h}$. In the absence of insulin treatment, negligible binding was observed. The observed kinetics of the insulin-induced binding activity may reflect new protein synthesis. To test for this requirement, cells were incubated with protein synthesis inhibitors, either cycloheximide $(10 \mu \mathrm{M})$ or puromycin $(100 \mathrm{mM})$, for $16 \mathrm{~h}$ before harvest. Cycloheximide treatment diminished the observed DNA binding in both control and insulin-treated groups. Cells were then incubated with $100 \mathrm{mM}$ puromycin for $16 \mathrm{~h}$. Puromycin treatment also blocked DNA-protein complex formation, confirming that the appearance of this binding activity requires protein synthesis (Fig. 4). Neither puromycin nor cycloheximide appeared to alter the nonspecific larger proteinDNA complexes, indicating a selective effect of these agents on the insulin-regulated protein-DNA complex.

The insulin-induced DNA-binding protein. To characterize the relative size of the insulin-induced DNA-binding protein, UV-protein cross-linking studies were performed in vitro. Extracts incubated with oligonucleotide probes A and B were electrophoresed in low melting agarose gels and irradiated at $305 \mathrm{nM}$ for $30 \mathrm{~min}$ at $4^{\circ} \mathrm{C}$. After autoradiography the specific

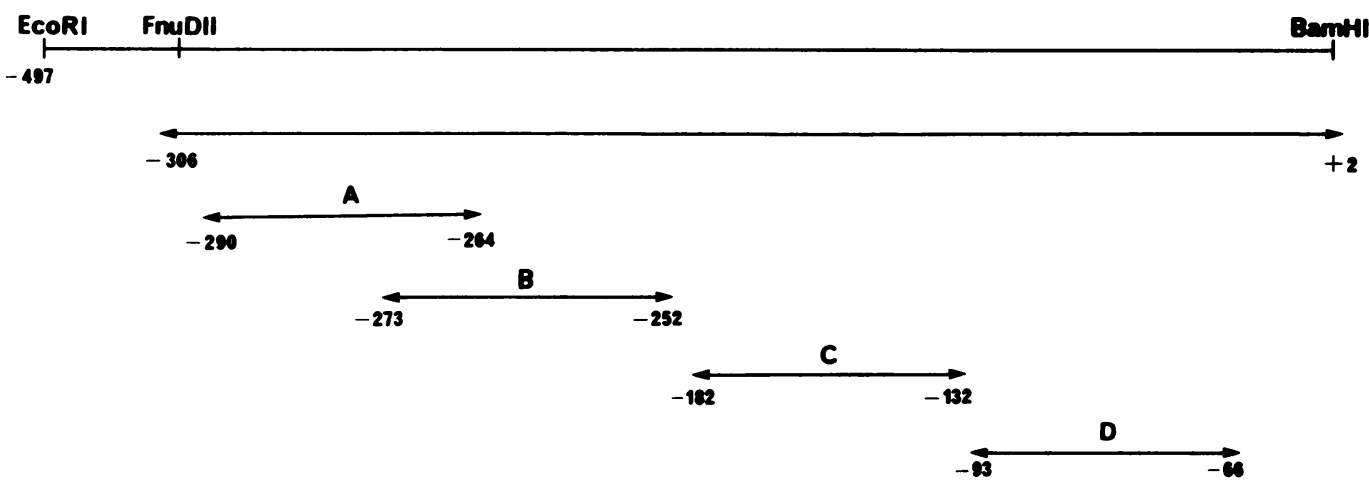

Figure 1. hGH promoter region with oligonucleotides $(A-D)$ shown. 


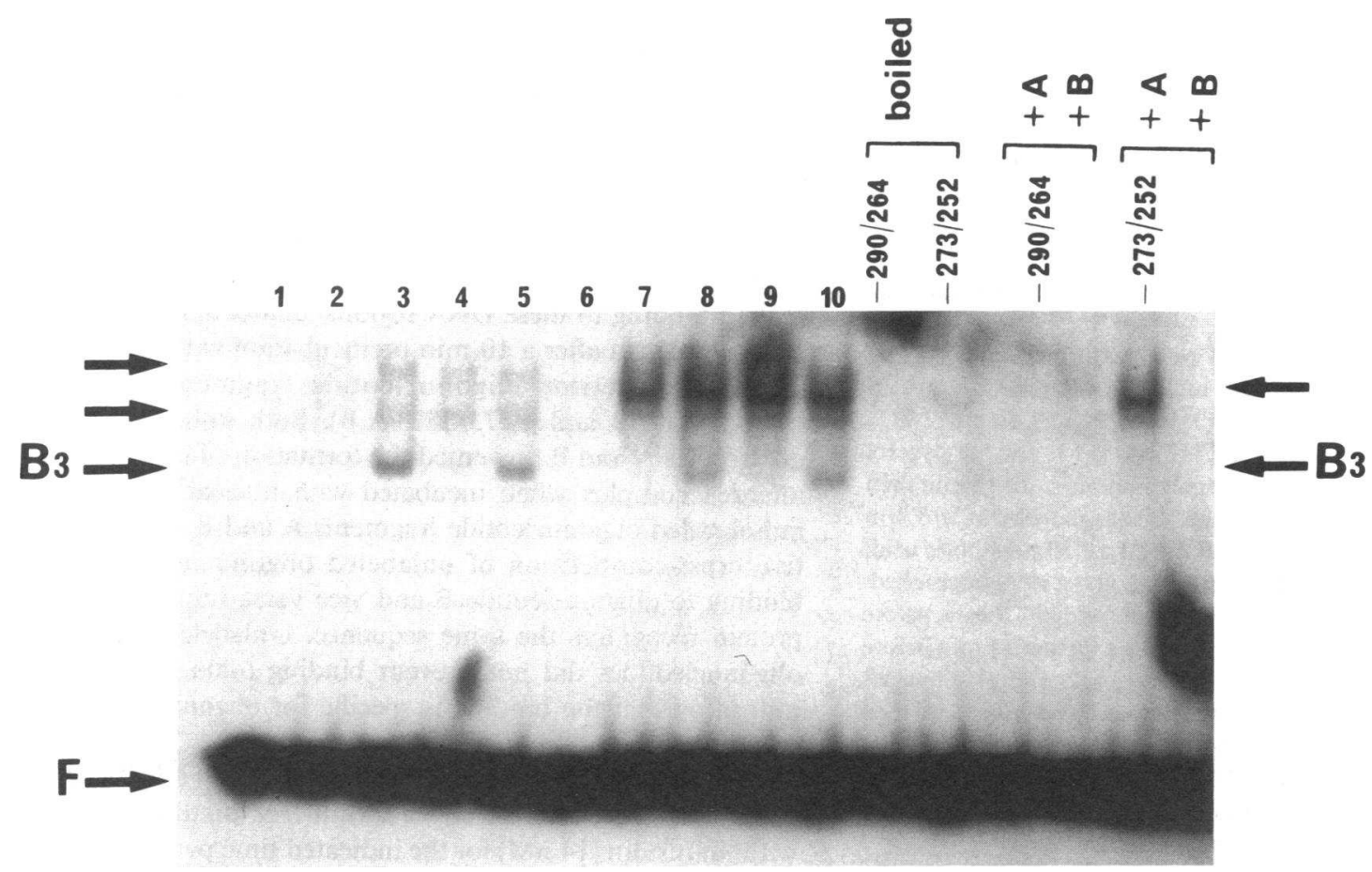

Figure 2. Insulin treatment of $\mathrm{CHO}$ cells induces a nuclear protein-DNA complex: localization of binding sites between -290 and -252 . Lane $1,-290 /-264$ probe alone; lanes 2 and $4,-290 /-264$ probe, $5 \mu \mathrm{g}$ CHO extract, $4 \mu \mathrm{g}$ poly (dI-dC); lanes 3 and $5,-290 /-264$ probe, $5 \mu \mathrm{g}$ insulin-treated (14 $\mathrm{nM}$ ) CHO extract, $4 \mu \mathrm{g}$ poly (dI-dC); lane 6, -273/-252 probe alone; lanes 7 and 9, $-273 /-252$ probe, $5 \mu \mathrm{g} \mathrm{CHO} \mathrm{extract,} 4 \mu \mathrm{g}$ poly (dI-dC); lanes 8 and $10,-273 /-252$ probe, $5 \mu \mathrm{g}$ insulin-treated CHO extract (14 nM), $4 \mu \mathrm{g}$ poly (dI-dC). The $-290 /-264$ and $-273 /-252$ probes were incubated with $5 \mu \mathrm{g}$ of $\mathrm{CHO}$ nuclear extract that had been boiled at $95^{\circ} \mathrm{C}$ for $5 \mathrm{~min}$, followed by $5 \mathrm{~min}$ on ice. ${ }^{32} \mathrm{P}$-labeled

$-290 /-264$ and $-273 /-252(1 \mathrm{ng}), 5 \mu \mathrm{g}$ insulin-treated CHO nuclear extract, and $4 \mu \mathrm{g}$ poly (dI-dC) were incubated with 100 -fold excess indicated competitor oligonucleotides (A and B, see Fig. 1). Arrows and B3 indicate bound complex. F, free DNA. B3 indicates insulin-induced bound complex.

DNA-protein complexes of interest were excised and electrophoresed on a $12 \%$ SDS-polyacrylamide gel. As two bands of 50 and $70 \mathrm{kD}$ were identified in the gels of the insulin-treated extracts, the possibility of an adjacent protein being crosslinked could not be excluded. Therefore, to further confirm the size of the DNA-binding protein, the mobility shift assay was performed using a 3-25\% gradient gel (23) with protein markers (Fig. 5). The gradient allows DNA-protein complexes to migrate at their true molecular weights, which can be compared with the prestained markers. The insulin-induced DNA binding protein appeared to migrate with a different molecular weight depending on which oligonucleotide probe was used. Mobility shift assays allow resolution of complexes formed by different proteins recognizing an identical sequence as long as the proteins differ significantly in their molecular mass and charges, thus allowing altered electrophoresis. Alternatively, two different proteins recognizing two different sequences within the same probe may generate an identical complex. Competition studies indicate that the protein(s) recognize the same DNA sequence, and the presence of two proteins cannot be excluded. Also, the relative contribution of oligonucleotide size ( $21 \mathrm{vs.} 26 \mathrm{bp}$ ) to the complex formation needs to be considered in interpreting the relative protein size.

\section{Discussion}

Although insulin has been shown to directly regulate the expression of several genes at the transcriptional level, no single insulin-responsive DNA sequence has yet been identified. Transfection studies using an hGH promoter chloramphenicol acetyl transferase reporter construct were used to localize insulin-responsive element(s) within $500 \mathrm{bp}$ of the GH promoter (14). In addition, DNAse I footprinting of the hGH promoter revealed three major protected regions (15). The proximal two protected sites bind the tissue-specific trans-acting factor, Pit I (GHF-I) (3). The third, distal site is protected by ubiquitous factors thought to be involved in cAMP and protein kinase $\mathrm{C}$ signal transduction (2). Using a mobility shift assay we identified an insulin-induced DNA-protein complex binding to the $-290 /-252$ region of the $\mathrm{GH}$ promoter, which corresponds to the distal footprinted site on the hGH promoter. Incubation of the protein extract with excess cold specific oligonucleotide sequences abolished binding, whereas similar-sized unrelated sequences did not compete for binding, confirming the specificity of the observed complex formation. Boiling the extract before its inclusion in the reactions prevented DNA-protein complex formation, suggesting that these nuclear factors are proteins. Novel DNA-protein interactions were detected by electrophoresis in the presence of high ionic strength buffer.

The observed insulin-induced binding activity could represent a nonbinding or low affinity form of the factor that undergoes insulin-mediated modification to generate a high affinity form of the protein or, alternatively, insulin could stimulate new protein synthesis. Kinetic analysis indicated that formation of the insulin-induced complex required $8 \mathrm{~h}$, and that this complex is still present after $16 \mathrm{~h}$ of insulin treatment. 


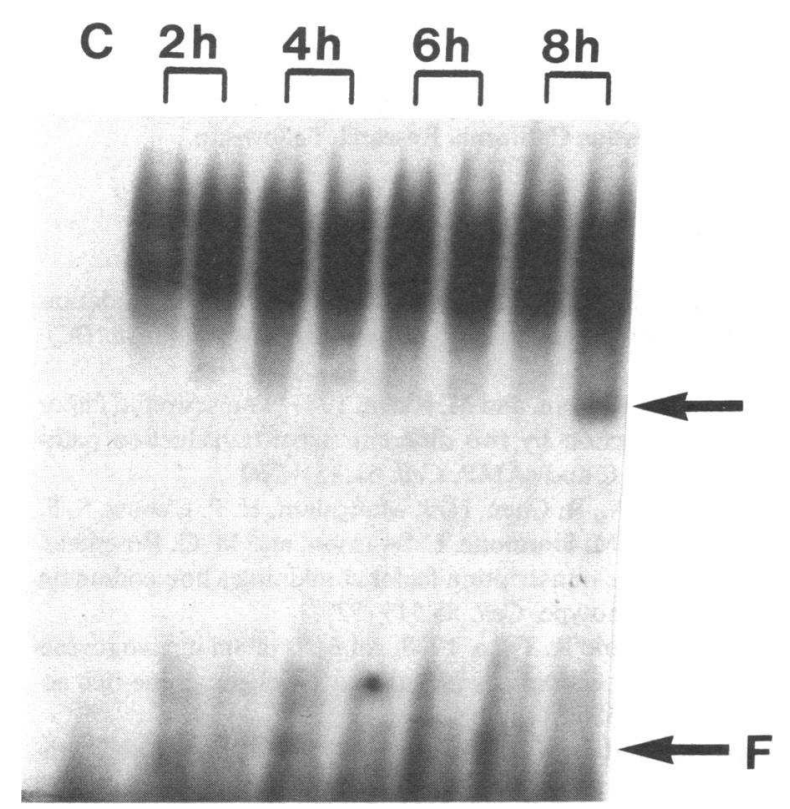

Figure 3. Kinetic analysis of insulin-induced DNA-protein complex formation. $\mathrm{CHO}$ cells were grown to confluence in Ham's F12+10\% (vol/vol) fetal calf serum and then deinduced in Ham's F12 and 1\% BSA. $14 \mathrm{nM}$ insulin was added for the indicated time periods, and each time point had a matching untreated control (left). ${ }^{32} \mathrm{P}$-labeled $-290 /-264$ oligonucleotide was incubated with $5 \mu \mathrm{g}$ insulin-treated $\mathrm{CHO}$ nuclear extract (time course as indicated), and $4 \mu \mathrm{g}$ poly (dIdC). Arrow, Insulin-induced bound complex; $F$, free DNA. Lane $C$, ${ }^{32} \mathrm{P}$-labeled $-290 /-264$ probe alone.

This relatively long lag period suggests that de novo protein synthesis is required. To confirm this requirement for new protein synthesis, cells were incubated with cycloheximide and puromycin, two different protein synthesis inhibitors, for $16 \mathrm{~h}$ before harvest. Both treatments, respectively, diminished the binding of the complex in control and insulin-treated cells, suggesting the presence of a labile protein. As many transcription factors are phosphoproteins (24), this insulin-mediated DNA-protein complex may be regulated by a posttranslational phosphorylation modification.

The rat PEPCK gene, murine c-fos gene, and murine amylase-2.2 gene contain insulin-responsive promoters $(6,11,12)$. Insulin dependence of an amylase gene in diabetic transgenic mice was analyzed, and insulin-responsive sequences were reported in the $5^{\prime}$ region of this gene (6). Two insulin-sensitive DNA-binding proteins have been identified on the human glyceraldehyde-3-phosphate dehydrogenase gene. The upstream binding site interacts with an insulin-sensitive DNAbinding protein in $3 \mathrm{~T} 3$ adipocytes. This sequence is supposedly present in a number of insulin-sensitive genes. The downstream element interacts with a trans-acting factor that is induced fourfold by insulin in 3T3 adipocytes (13). Alignment of the promoter regions of these three genes and the hGH gene reveals homologous regions as indicated in Table I. Nuclear proteins extracted from a variety of cell types contained binding factors detectable by mobility shift assay that bound in a sequence-specific manner to the hGH promoter. Although the DNA-binding protein is not tissue specific, its quantitative regulation by insulin appears to be cell specific.

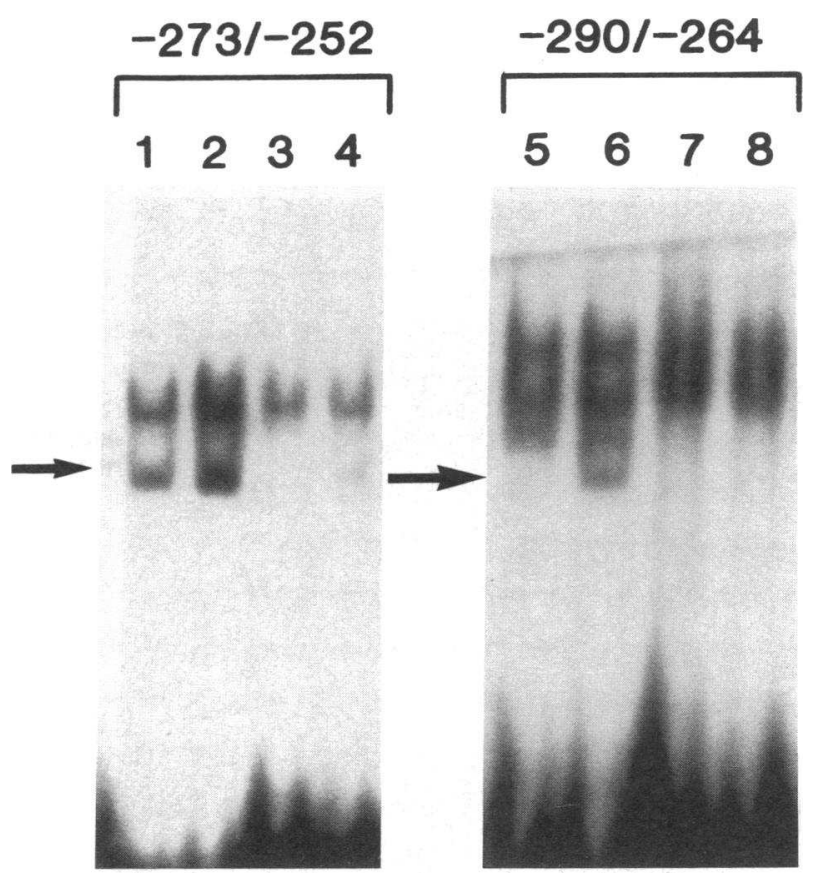

Figure 4. Effect of puromycin on insulin-induced nuclear proteinDNA complex binding to the $-290 /-264$ and $-273 /-252$ sequences. CHO cells were incubated with $100 \mathrm{mM}$ puromycin for 16 $\mathrm{h}$ before harvest. All lanes contain $5 \mu \mathrm{g}$ of nuclear extract and $4 \mu \mathrm{g}$ poly (dI-dC). Lanes $1-4$ were incubated with the $-273 /-252$ probe. Lanes 5-8 were incubated with the $-290 /-264$ probe. Lanes 1 and 5 , probe, poly (dI-dC), CHO extract; lanes 2 and 6, probe, poly (dI$\mathrm{dC})$, insulin (14 nM)-treated nuclear extract; lanes 3 and 7 , probe, poly (dI-dC), puromycin-treated extract; lanes 4 and 8 , probe, poly (dI-dC), puromycin, and insulin-treated extract. Arrows, Insulin-induced DNA-protein complex.

DNA-protein complex migration is determined by $\mathrm{pH}$, salt concentration, complex conformation, and the molecular mass of the proteins. The differences in complex size observed with the gradient gel and oligonucleotides A and B may be indicative of two different proteins recognizing an identical sequence. However, the DNA-binding competition experiments suggest that the protein is recognizing the identical sequence.

The hGH gene was reported to contain sequences interacting with two DNA-binding factors $(-308 /-235)$ mediating

Table I. Sequence Homology in the Promoter Region of Four Insulin-responsive Genes

\begin{tabular}{lrcrrl}
\hline \multicolumn{1}{c}{ Gene } & \multicolumn{1}{c}{$5^{\prime}$} & \multicolumn{1}{c}{ Sequence } & \multicolumn{1}{c}{$3^{\prime}$} & Match & \multicolumn{1}{c}{ Strand } \\
\hline GH & -287 & ATGGCCTGCGG & -277 & & Coding \\
c-fos & -296 & ATGTCCTAATA & -306 & $6 / 11$ & Noncoding \\
PEPCK & -202 & GAGGCCTCAGG & -88 & $7 / 11$ & Noncoding \\
PEPCK & -78 & GAGGCCTCAGG & -202 & $7 / 11$ & Noncoding \\
Amy-2.2 & -223 & ATGGCCTCAGA & -223 & $8 / 11$ & Coding \\
Amy-2.2 & -185 & ATGGCCTCAGA & -175 & $8 / 11$ & Coding \\
& & & & & \\
\hline
\end{tabular}

Depicted sequences $(14,11,12,6)$ were aligned with the 11 base pairs of the hGH promoter region $(-287 /-277)$. 


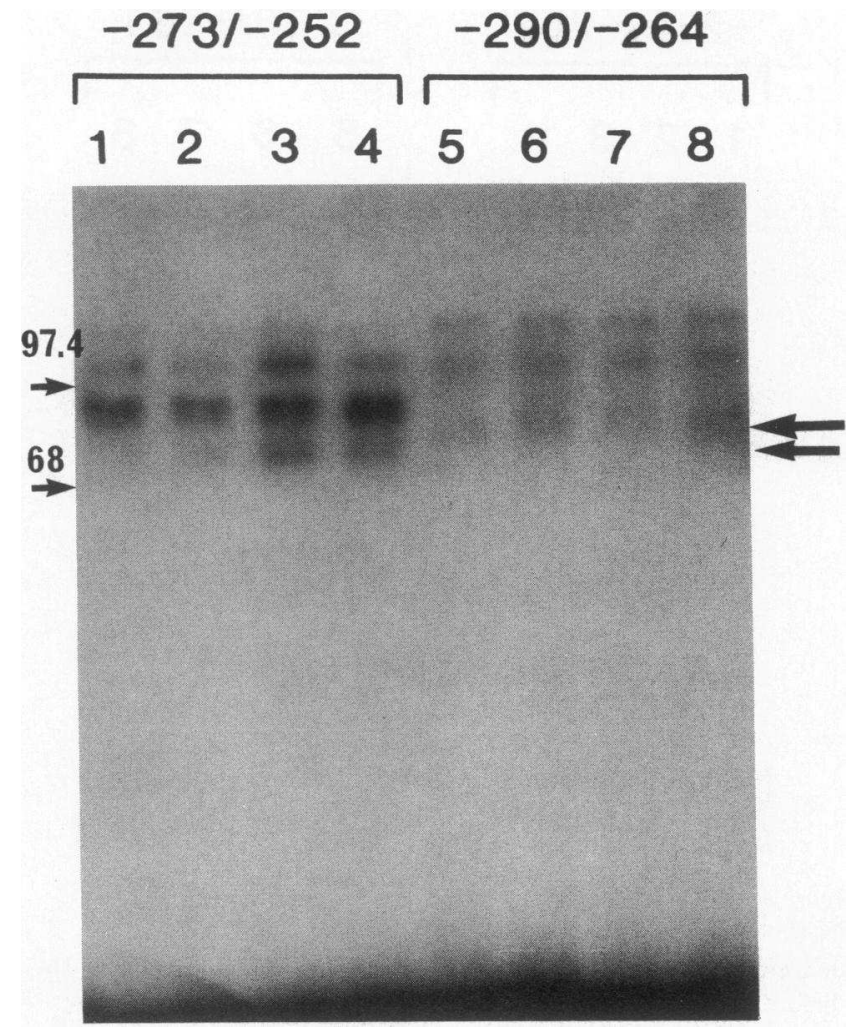

Figure 5. Nuclear protein sizing by gradient gel electrophoresis. After incubation with the indicated oligonucleotide probes, DNA-protein complexes were separated on 3-25\% gradient polyacrylamide gels together with prestained high molecular weight protein standards. Lanes 1-4 were incubated with the $-273 /-252$ probe. Lanes $5-8$ were incubated with the $-290 /-264$ probe. All lanes contain $5 \mu \mathrm{g}$ of CHO extract and $4 \mu \mathrm{g}$ poly (dI-dC). Lanes $1,2,5$, and 7 , probe, poly (dI-dC), and CHO nuclear extract. Lanes $3,4,6$, and 8 , probe, poly (dI-dC), insulin (14 nM)-treated nuclear extract. Arrows, Insulin-regulated protein, molecular mass $70-80 \mathrm{kD}$. Protein sizes (kD) are indicated on the left.

positive and negative transcriptional control (25). One of these factors binding between $-275 /-257$ was reported to be related to major late transcription factor, the upstream stimulatory factor that activates adenovirus major late promoter transcription. The other factor detected with the $-308 /-235$ fragment acted as a dominant repressor of gene expression. Although the relationship between these factors and the insulininduced DNA-binding protein is presently unclear, insulin does suppress the GH promoter even though it induces this DNA-binding factor. Therefore, this trans-acting factor could be acting as a repressor of transcription.

DNA-binding transcription factors have distinct binding and transcriptional activation domains (26). It should therefore be possible to test the functional significance of this insulin-mediated DNA-binding activity to these elements of the hGH gene promoter.

\section{Acknowledgments}

The authors are grateful to Grace G. Labrado for excellent typing assistance.
Work in the authors' laboratory was supported in part by grants from the National Institutes of Health (DK-34824) and by a grant from the Juvenile Diabetes Foundation. D. Prager is a recipient of an American Diabetes Association California Research Fellowship.

\section{References}

1. Maniatis, T., S. Goodbourn, and J. A. Fischer. 1987. Regulation of inducible and tissue-specific gene expression. Science (Wash. DC). 236:1237-1244.

2. Imagawa, M., R. Chiu, and M. Karin. 1987. Transcription factor AP-2 mediates induction by two different signal-transduction pathways: protein kinase $C$ and cAMP. Cell. 51:251-260.

3. Ingraham, H. A., R. Chen, H. J. Mangalam, H. P. Elshotz, S. E. Flynn, C. R. Lin, D. M. Simmone, L. Swanson, and M. G. Rosenfeld. 1988. A tissue-specific transcription factor containing a homeodomain species pituitary phenotype. Cell. 55:519-529.

4. Courey, A. J., and R. Tjian. 1988. Analysis of Spl in vivo reveals multiple transcriptional domains including a novel glutamine-rich activation motif. Cell. 55:881-898.

5. Sasaki, K., and D. K. Granner. 1988. Regulation of phosphoenolpyruvate carboxykinase gene transcription by insulin and cAMP: reciprocal actions on initiation and elongation. Proc. Natl. Acad. Sci. USA. 85:2954-2958.

6. Osborn, L., M. P. Rosenberg, S. A. Keller, C. N. Ting, and M. H. Meisler. 1988. Insulin response of a hybrid amylase/CAT gene in transgenic mice. Biol. Chem. 263:16519-16522.

7. Strauss, D. S., and C. D. Takemoto. 1987. Insulin negatively regulates albumin mRNA at the transcriptional and post-transcriptional level in rat hepatoma cells. J. Biol. Chem. 262:1955-1960.

8. Yamashita, S., and S. Melmed. 1986. Insulin regulation of growth hormone gene transcription. J. Clin. Invest. 78:1008-1014.

9. Podlecki, D. A., R. M. Smith, M. Kao, P. Tsai, T. Huecksteadt, D. Brandenburg, R. S. Lasher, L. Jarett, and J. M. Olefsky. 1987. Nuclear translocation of the insulin receptor: a possible mediator of insulin's long-term effects. J. Biol. Chem. 262:3362-3368.

10. Kahn, C. R. 1985. The molecular mechanism of insulin action. Annu. Rev. Med. 36:429-451.

11. Stumpo, D. J., T. N. Stewart, M. Z. Gilman, and P. J. Blackshear. 1988. Identification of $\mathrm{c}$-fos sequences involved in induction by insulin and phorbol esters. J. Biol. Chem. 263:1611-1614.

12. Magnuson, M., P. Quinn, and D. Granner. 1987. Multihormonal regulation of phosphoenolpyruvate carboxykinase chloramphenicol acetyltransferase fusion genes. J. Biol. Chem. 262:1491714920.

13. Alexander, M. C., M. Lomanto, N. Nasrin, and C. Ramaika. 1988. Insulin stimulates glyceraldehyde-3-phosphate dehydrogenase gene expression through cis-acting DNA sequences. Proc. Natl. Acad. Sci. USA. 85:5092-5096.

14. Prager, D., and S. Melmed. 1988. Insulin regulates expression of the human gene in transfected cells. J. Biol. Chem. 203:1658016585 .

15. Lefevre, C., M. Imagawa, S. Dan, J. Grindlay, M. Bodner, and M. Karin. 1987. Tissue-specific expression of the human growth hormone gene is conferred in part by binding of a specific trans-acting factor. EMBO (Eur. Mol. Biol. Organ.) J. 6:971-981.

16. Poretsky, L., and M. F. Kalin. 1987. The gonadotropic function of insulin. Endocr. Rev. 8:132-140.

17. Caro, J. F., and R. L. Rosenfield. 1988. Insulin-like growth factor I and Insulin potentiate luteinizing hormone-induced androgen synthesis by rat ovarian thecal interstitial cells. Endocrinology. 123:733-739.

18. Bhandari, B., R. H. Wilson, and R. E. Miller. 1987. Insulin and dexamethasone stimulate transcription of an amplified glutamine synthetase gene in chinese hamster ovary cells. Mol. Endocrinol. 1:403407. 
19. Podskalny, J., A. McElduff, and P. Gordon. 1984. Insulin receptors on Chinese hamster ovary (CHO) cells: altered insulin binding to glycosylation mutants. Biochem. Biophys. Res. Commun. 125:7075.

20. Dignam, J. D., R. M. Lebovitz, and R. G. Roeder. 1983. Accurate transcription initiation by RNA polymerase II in a soluble extract from isolated mammalian nuclei. Nucleic Acids Res. 11:1475-1489.

21. Bradford, M. M. 1976. A rapid and sensitive method for the quantification of microgram quantities of protein utilizing the principle of protein dye binding. Anal. Biochem. 72:248-254.

22. Distel, R. J., H. S. Ho, B. S. Rosen, D. L. Groves, and B. M. Spiegelman. 1987. Nucleoprotein complexes that regulate gene expression in adipocyte differentiation: direct participation of c-fos. Cell. 49:835-844.
23. Rodriguez, R., and W. T. Schrader. 1989. A reversible native gel electrophoresis method for studying the composition of steroid receptor-DNA complexes. The Endocrine Society, 71st Annual Meeting, Seattle, WA. A568.

24. Gonzalez, G. A., and M. R. Montminy, 1989. Cyclic AMP stimulates somatostatin gene transcription by phosphorylation of CREB at serine 13. Cell. 59:675-680.

25. Peritz, L. N., J. B. Fodore, D. W. Silversides, P. A. Cattini, J. D. Baxter, and N. L. Eberhardt. 1987. The human growth hormone gene contains both positive and negative control elements. J. Biol. Chem. 263:5005-5007.

26. Mitchell, P. J., and R. Tjian. 1989. Transcriptional regulation in mammalian cells by sequence-specific DNA binding proteins. Science (Wash. DC). 245:371-378. 